\title{
The Path of Inner Purification in Yoga
}

\author{
MS Srinivasan* \\ Research Associate, Sri Aurobindo Society, India
}

Submission: October 12, 2018; Published: April 12, 2019

*Corresponding author: MS Srinivasan, Degree in Electrical and Electronics engineering, Research Associate, Sri Aurobindo Society, India

\begin{abstract}
Inner purification of the mind and heart is an indispensable preparatory discipline in the path of Yoga. This article is a brief review of the principles and practice of this discipline of Yoga.

Keywords: Inner purification; Preparatory; Path of yoga; Discipline of yoga; Purity; Psychological; Yamaniyama; Inertia; Laziness; Indolence; Unwillingness to change pride; Vanity; Arrogance; Anger; Violence; Greed; Patanjali's yoga sutra; Desire; Discipline of purity
\end{abstract}

\section{The Two Levels of Purity}

The Indian yogic tradition laid a great stress on "purity". But what is precisely this "purity" which Vivekananda is talking about? From a yogic perspective, there are two levels of purity: spiritual and psychological or sattwic. The spiritual purity comes from total freedom from all forms of ego and desire, which are the source of all impurity. The psychological purity comes from a relative freedom from and mastery over some basic impediments to spiritual progress like for example, inertia, laziness, indolence, unwillingness to change pride, vanity, arrogance, anger, violence, greed' lust which are the children of Rajas.

The path to this second kind of psychological purity is through governance of our mind, heart and body by sattwic intelligence and will of our higher mind which seeks for truth, knowledge, harmony and virtues. This sattwic purity is the aim of Yamaniyama discipline of Patanjali's yoga sutra. The path to spiritual purity is through the governance of our entire human nature -physical, emotional and mental - by the divine spark within everyone, called as psychic being in the integral yoga of Sri Aurobindo. The psychic being is the evolving divinity dwelling in the depth of our heart and it is the only part within us which is entirely free from ego and desire.

We must note here that from a yogic perspective sattwic purity is not spiritual because it is still tainted by sattwic ego and the nobler desires of the sattwic mind like the desire for knowledge and virtues. Bhagavad Gita says that sattwa binds by its attachment to "knowledge and happiness." sattwic ego can be subtle hiding itself behind noble and lofty masks. An example of sattwic ego is the attitude of a school of Indian philosophy to other schools and systems of thought, which is somewhat like this. "My philosophical ideal or experience is the highest. Your ideals and experience are at the lower, preparatory stages. When you reach my level of spiritual maturity and development you will understand that my ideal and experience is the highest goal of religion, philosophy and spirituality and we will all agree and meet together. Until then I will wait for you with a compassionate tolerance looking down at you from my high pedestal of superiority as you climb slowly towards my level of highest attainment."

However, we cannot leap from a state of gross impurity to spiritual purity. We must pass through a stage of sattwic purity to reach the highest spiritual purity of our psychic being.

\section{The Discipline of Purity}

In terms of practice, the discipline for sattwic purity is a vigilant self-control over all the impulses of our love and nature and replacing them with sattwic impulses towards peace and calm, knowledge and understanding, truth charity and kindness. The discipline for spiritual purity involves three aspects: the first one is a progressive inner detachment from all the inner movements of our mind and heart and observe them as an uninvolved witness. This gives a deep understanding of how Nature works in us and how we are driven helplessly and unconsciously by them like a robot. The other discipline is to learn to listen and act according to the inner guidance of the psychic being which is the true self in us. To do this effectively we have to follow the third part of the discipline which is to progressively eliminate ego and desire from all the levels of our being - physical, vital, emotional and mental. 
In the yogic perspective the concept of ego is deeper and wider than the popular conception of it. Ego is the element or principle in us which gives us the sense if "I" and "Mine" and identifies itself with whatever that is or happens within the field of its awareness. We normally associate ego with pride, vanity, arrogance or a sense of superiority. But this is only one form of ego when it identifies itself with its capacities or achievement. The ego can identify itself with its weakness and say, "I am a weak, hopeless and miserable person". There can also be a sattwic ego which can identify itself with its virtues like humility or selflessness and think of itself "what a humble person I am" or "see how selflessly I am serving the poor". In our normal human consciousness, the ego-principle pervades our whole being and every inner and outer movement and activity of our being and hides behind our noble impulses with a subtle self-seeking and hundreds of subterfuges. So, it is not easy to get rid of the ego. It requires a deep vigilant and constant self-observation to detect and dislodge the all-pervading clutch of our ego. Even when we are able to get rid of this ego in the form of "I" and "mine", behind it there is a deeper substratum of ego which is the source of the sense of separateness we feel from others and make us feel that "I am someone distinct and separate from others." This is the innermost source of our ego which can be dissolved only when we raise above the mind into the unity-consciousness of our spiritual self, where we feel all others and the entire creation as a part of our own self.

Similarly, with desire, which takes different forms at various levels of our living. The core or essence of desire is attachment to things and objects of the outer or inner world. At the lower level it is the desire or attachment to wealth, enjoyment or pleasure, power, name and fame, success. In our faculties of action, it is the desire for the fruits and results of our action. At a higher more mental and moral level it is the attachment to knowledge, happiness or some moral virtues like charity or to ideas or ideal like nonviolence or a way of thinking or looking at life like for example the scientific, pragmatic, religious, secular or some "isms" like socialism, capitalism or democracy. To achieve spiritual purity all these desires and attachments must be renounced.

\section{Conclusion}

Inner purity is the indispensable foundation for spiritual progress is Yoga. These are two kinds of purity which must be achieved in Yoga: Psychological and Spiritual. To attain this double purity requires rigorous inner discipline of consciousness.

Your next submission with Juniper Publishers
will reach you the below assets
- Quality Editorial service
- Swift Peer Review
- Reprints availability
- E-prints Service
- Manuscript Podcast for convenient understanding
- Global attainment for your research
- Manuscript accessibility in different formats
( Pdf, E-pub, Full Text, Audio)
- Unceasing customer service
Track the below URL for one-step submission
https://juniperpublishers.com/online-submission.php

